Marwah: Jurnal Perempuan, Agama dan Jender (p-ISSN: 1412-6095 | e-ISSN: 2407-1587)

Vol. 17, No. 1, 2018, Hal. 42 - 62

\title{
KEWENANGAN DAN KEDUDUKAN PEREMPUAN DALAM PERSPEKTIF GENDER: SUATU ANALISIS TINJAUAN HISTORIS
}

\author{
HENDRI HERMAWAN ADINUGRAHA \\ Universitas Dian Nuswantoro Semarang, Indonesia \\ bendri.bermawan@,dsn.dinus.ac.id
}

ASEP SURAYA MAULANA

UIN Walisongo Semarang, Indonesia

Ranaa97@yahoo.com

MILA SARTIKA

Universitas Dian Nuswantoro Semarang mila.sartika@,dsn.dinus.ac.id

\begin{abstract}
The purpose of this aticle is to describe the authority and position of women in a gender perspective with an analysis based on a historical approach. This type of research was library research by using content analysis techniques in data processing. The results of this study has been shown that in pre-Islamic era in the Arab Jahiliyyah culture, women received unequal treatment with men (not indicating gender equality). But after Islam came, the teachings of Islam raised the dignity of women, which distinguishes women and men by Allah only the value of his piety. In the classical period (the prophet's period), women have an important role in all aspects of life, such as in the field of transmission of hadith, war, commerce, and so forth. In the midperiod (Islamic dynasties period), women began to have an important role in political life and state.
\end{abstract}

Keywords: history, women, authority, position, and gender

\begin{abstract}
ABSTRAK
Tujuan artikel ini ialah untuk mendeskripsikan tentang kewvenangan dan kedudukan perempuan dalam perspektif gender dengan analisis yang berdasarkan pada pendekatan historis. Jenis penelitian ini termasuk penelitian pustaka (library research) dengan menggunakan teknik analisis isi (content analisys) dalam mengolah datanya. Hasil kajian ini menunjukan bahwa pada zaman pra Islam dalam budaya masyarakat Arab Jabiliyyah, perempuan mendapat perlakuan yang tidak setara dengan laki-laki (tidake menunjuke.ean adanya kesetaraan gender). Namun setelah Islam datang, ajaran Islam mengangkat harkat dan martabat perempuan, yang membedakan perempuan dan laki-laki di sisi Allab hanya nilai taqwanya. Pada periode klasik (zaman nabi), perempuan memiliki peran penting dalam selurub aspek kehidupan, seperti dalam bidang periwayatan hadist, perang, berniaga, dan lain sebagainya. Pada periode pertengahan (zaman dinasti-dinasti Islam), perempuan mulai memiliki peran penting dalam kebidupan politik dan bernegara.
\end{abstract}

Kata Kunci: histori, perempuan, kewvenangan, kedudukan, dan gender 


\section{A. PENDAHULUAN}

Sejarah penciptaan manusia tidak terlepas dari kisah Adam dan Hawa. Kata Adam sering kali mewakili jenis kelamin laki-laki dan Hawa mewakili jenis kelamin perempuan. Perempuan merupakan salah satu makhluk ciptaan Allah yang dipasangkan dengan manusia dengan jenis kelamin laki-laki. Sejak pertama kali diciptakannya manusia, Adam diciptakan berpasangan dengan Hawa. Namun, ketika membicarakan tentang kesetaraan gender antara perempuan dan laki-laki, seringkali kisah yang menyebutkan bahwa Hawa diciptakan dari tulang rusuk Adam dan peristiwa diturunkannya Adam dan Hawa ke bumi karena memakan buah khuldi dipahami secara berbeda-beda sehingga menjadi suatu perdebatan terkait persoalan kesetaraan perempuan dan laki-laki. Sejarah Islam mencatat, kedudukan dan peran perempuan mengalami pasang surut sesuai dengan budaya masyarakat yang berlaku dalam masanya. Pada masa pra-Islam posisi perempuan berbeda dengan masa Islam.

Pada masa Islam dapat dikategorikan menjadi 3 masa yakni masa klasik, pertengahan, dan modern. Dalam pernikahan, banyak jenis pernikahan dalam budaya bangsa Arab masa pra Islam yang kebanyakan sangat merugikan dan menindas kaum perempuan. Kaum perempuan tidak dihargai, dalam pernikahan hanya dijadikan sebagai barang komoditi yang bisa diwariskan atau dipertukarkan tanpa ada kesepakatan terlebih dahulu dari pihak perempuan. Banyak hal terkait dengan gender diantaranya; perempuan dalam keluarga, sebagai kepala Negara, dan lain-lain. Berkat hadirnya Nabi Muhammad yang membawa ajaran Islam kedudukan perempuan dimulyakan, diangkat harkat dan martabatnya, dan mendapat hak-hak sebagai manusia.

Hasil penelitian Mohd Anuar Ramli (2012) mengungkapkan bahwa realita kedudukan perempuan dalam masyarakat muslim sangat berbeda antara satu sama lain dan hal itu perlu ditanggapi dengan cermat dari perspektif dalam masyarakat itu sendiri (ethnocentrism). Hal senada juga diungkapkan oleh Fadlan (2011), penyebab terjadinya perbedaan perspektif mengenai kewenangan dan kedudukan permpuan dalam masyarakat muslim adalah keyakinan bahwa perempuan adalah makhluk Allah yang lebih rendah karena diciptakan dari tulang rusuk yang bengkok. Selain itu, perempuan dianggap sebagai makhluk yang kurang pengetahuan sehingga harus selalu berada dalam bimbingan lakilaki. Akibatnya, produk-produk pemikiran Islam sering menempatkan perempuan sebagai subordinat. Fakta dan realita ini tentu sangat memprihatinkan, karena Islam pada 
hakikatnya sangat menjunjung tinggi kesetaraan dan tidak membedakan manusia berdasarkan jenis kelamin (melainkan karena nilai taqwanya kepada Allah).

Perempuan dalam perspektif Islam memiliki hak dan kewajiban yang sama (setara) dengan laki-laki. Baik perempuan maupun laki-laki memiliki hak pahala perbuatan baik, dan hukuman untuk perbuatan buruk, serta memiliki kewajiban ibadah yang sama (Hasyim, 2012). Islam juga memandang laki-laki dan perempuan adalah kesatuan yang berpasangan (Mutawakkil, 2014). Dengan demikian terkait itu semua, artikel ini berusaha untuk mendeskripsikan tentang kewenangan dan kedudukan perempuan dalam perspektif gender dengan analisis yang berdasarkan pada pendekatan historis.

\section{B. PEMBAHASAN DAN ANALISIS}

\section{Perkembangan Makna Gender}

Kata "gender” secara leksikal berasal dari bahasa Inggris, atau "GescbJeche" bahasa Jerman), "Genre" bahasa Perancis), "Genero" bahasa Spanyol), yang artinya semacam jenis, ras dan kelas, dan "generare" Bahasa Latin) yang artinya prokreasi atau bisa juga bermakna ras atau jenis. Pengertian kata "jender" (menggunakan huruf "j” karena sudah diadopsi dalam bahasa Indonesia) atau "gender" datam kamus-kamus bahasa Inggris ataupun bahasa Indonesia tidak dibedakan dengan pengertian jenis kelamin. Dalam kamus umum Bahasa Indonesia, kata gender diartikan dengan gender, bagian gamelan Jawa yang dibuat dengan bilah-bilah logam yang pipih dengan penggema bunyi dari bambu (Badudu dan Zain, 2001). Gender menurut Victoria Neuvelt (1984) memiliki makna "The apparent disparity between man and women in values nd behavior" dalam arti lain juga diartikan sebagai "perbedaan yang tampak antara laki-laki dan perempuan dilihat dari segi nilai dan tingkah laku"

Pengertian kata "gender" dalam kamus umum bahasa Inggris, misalnya Oxford Advanced Learner s Dictionary, diartikan dengan dasifficaaon ofa nown orprtmoun as moscute arfeminine; sexud dasifficatian; sex: the mok and femak genders (klasifikasi benda atau kata ganti benda sebagai maskulin atau feminin; klasifikasi seksual; seks: gender lakilaki dan gender perempuan). Gender dalam pandangan Helen Tierney (1993) merupakan konsep kultural yang telah mengupayakan membuat pembedaan peran, perilaku, metalitas, karakteristik emosional antara laki-laki dan perempuan yang sudah berkembang dalam masyarakat luas. 
Pada perkembangannya, sekitar abad 14, kata gender dalam bahasa Inggris digunakan dengan pengertian umum sebagaimana disebut di atas (jenis dan kelas). Dalam bahasa Perancis, Jerman dan Spanyol, seperti juga dalam bahasa Inggris, katakata yang terkait dengan istilah gender juga merujuk pada kategori yang bersifat gramatikal dan literer. Dalam bahasa Inggris modern dan bahasa German kata gender dan geschlecht dekat artinya dengan konsep seks, seksuality, perbedaan seks, generasi, dan prokreasi. Gender secara umum merupakanjantung dari konstruksi dan klasifikasi sistem perbedaan. Gender sebagai sebuah konsep yang secara teoritis dipahami berbeda dengan jenis kelamin diperkenalkan pertama kali oleh seorang ahli sosiolog Inggris, Ann Oakley pada tahun 50-an seiring dengan munculnya gelombang kedua feminisme (Rohmaniyah, 2009). Bahkan menurut Abdul Karim (2014) feminisme menjadi salah satu alternatif model dalam melakukan penelitian kualitatif. Secara umum feminisme menurut Islam menjadi gerakan atau alat analisis yang bersifat historis dan konstekstual seiring dengan kesadaran yang terus berkembang dalam menjawab semua persoalan yang dihadapi perempuan menyangkut ketidakadilan dan ketidaksetaraan (Suryorini, 2012).

Gender sebagai sebuah kategori sosial, kultural historis dan politis mulai dianggap penting pada tahun 70 -an. Dalam khasanah ilmu-ilmu sosial istilah gender digunakan dengan makna khusus yang secara fundamental berbeda dengan jenis kelamin yang bersifat biologis. Hampir semua teori tentang gender dan argumen yang dikemukakan didasarkan pada pembedaan yang bersifat konseptual antara jenis kelamin yang bersifat biologis dan gender yang bersifat sosial. Dalam rumusan ilmuilmu sosial relasi gender diartikan dengan sekumpulan aturan-aturan, tradisi-tradisi, dan hubunganhubungan sosial timbal balik dalam masyarakat dan dalam kebudayaan, yang menentukan batas-batas feminin (dianggap bersifat keperempuanan) dan maskulin (dianggap bersifat kelelakian)." Konsep gender mengacu pada perbedaanperbedaan antara perempuan dengan laki-laki yang merupakan bentukan sosial (Macdonald, et all, 1999). Dengan kata lain, gender adalah penentuan maskulinitas dan feminitas yang dibangun secara sosial dan kultural dan dengan demikian identitas gender dapat berubah dan berbeda dalam ruang dan waktu yang berbeda. 


\section{Sejarah Gender dari Masa ke Masa}

\section{a. Gender Masa Sebelum Islam}

Berdasarkan catatan sejarah, sebelum turunnya Alqur'an, dunia telah memiliki beberapa peradaban besar. Diantaranya adalah Cina, India, Roma, Yunani, Babilon, Persia dan Mesir. Dalam peradaban kuno dan sepanjang masa, status perempuan selalu mengalami perubahan. Meskipun adakalanya mereka dihormati, namun berbagai penindasan dan perlakuan negatif seringkali menimpa kehidupan kaum perempuan. Banya orang tidak memilik rasa kemanusiaan terhadap perempuan dengan berbagai alasan, karena tradisi ataupun karena adat. Sebelum kedatangan konfusius, para ibu di Cina diperlakukan dengan rasa hormat. Namun di bawah pemerintahannya, menurut Will Durant dalam bukunya Qissat al-Hadarah yang dikutup oleh Fatimah Umar Nasif menyebutkan seorang ayah memiliki kekuasaan yang mutlak dan bersifat tirani mengenai semua persoalan keluarga, dia bahkan mempunyai hak untuk menjual isteri dan anaknya sebagai budak (Nasif, 2001).

Menurut Quraish Shihab, dalam peradaban Cinadan Hindu, kehidupan perempuan tidak lebih baik dari peradaban Yunani dan Roma, dimana hak hidup seorang perempuan yang bersuami harus berakhir pada saat kematian suaminya. Isteri pun harus dibakar hidup-hidup pada saat mayat suami dibakar. Dalam peradaban Roma, perempuan sepenuhnya berada di bawah kekuasaan ayahnya. Setelah menikah, kuasaan tersebut berpindah ke tangan sang suami. Kekuasaan ini mencakup kewenangan menjual, mengusir, menganiaya dan membunuh. Hukum Roma mencabut dan menghilangkan hak-hak sipil kaum perempuan, dan segala hasil usaha perempuan menjadi hak milik keluarganya yang laki-laki (Shihab, 1996).

Perempuan juga dianggap sebagai objek, dimana suami membayar sejumlah uang tertentu kepada ayah sang isteri, dan sebagai imbalannya isteri harus melakukan semua pekerjaan rumah tangga dan pekerjaan lainnya tanpa boleh menolak. Isteri tidak mempunyai hak untuk mengajukan keberatan atas semua ketidakadilan tersebut, bahkan seorng isteri tidak memiliki hak untuk menuntut kekayaan suaminya setelah suaminya meninggal dan jika mau, suami boleh mencabut hak waris bagi isterinya. Bangsa Yahudi yang dikenal sebagai sentral dan sumber peradaban dunia modern, dalam memperlakukan perempuannya tidaklah berbeda dari peradaban-peradaban lainnya. Walaupun bangsa Yahudi telah lebih maju dari pada bangsa lain di bidang ilmu pengetahuan, namun tetap saja anak-anak 
perempuan tidak memiliki hak untuk mendapatkan pengetahuan itu. Jika anak-anak perempuan dari kelas atas masih dapat memperoleh pelajaran membaca dan menulis dirumahnya, tidak demikian dengan anak-anak perempuan dari kelas bawah. Mereka hanya dapat memperoleh pengetahuan agama dari ibu mereka yang juga bodoh, sambil mengerjakan pekerjaan rumah (Nasif, 2001).

Menurut Anas Qasim dalam bukunya al-Huquq al-Siyasiyah li al-Mar'ah menjelaskan bahwa kondisi laki-laki di Yunani demikian perkasa. Misalnya, pada saat itu lelaki boleh menikahi perempuan tanpa ada batasnya. Kalu sudah dinikahi, perempuan dianggap sebagai milik mutlak laki-laki yang menikahinya. Dalam arti kata, perempuan bisa diperlakukan sesuai dengan kemahuan lelaki yang memilikinya. Yunani yang merupakan pusat ilmu pengetahuan pada saat itu, dengan tokoh-tokohnya seperti, Plato dan Aristoteles yang merupakan tokoh besar yang meletakkan kaum perempuan pada posisi inferior, dan teori Aristoteles tersebut tidak hanya mempengaruhi pemikiran dunia barat saja, tetapi juga mampu mempengaruhi pemikiran dunia Islam, dan akhirnya tidak dapat disangkal jika peminggiran kaum perempuan terjadi disegala bidang (Hasyim, 2001).

Sejarah kehidupan kaum perempuan pada masa pra-Islam hingga datangnya Islam, meliputi sejarah suatu masa yang oleh para intelektual disebut masa jahiliyah, yaitu suatu masa sebelum datangnya Islam yang selalu diidentifikasikan dengan zaman kegelapan. Istilah jahiliyah secara umum merupakan kata serapan dari istilah Arab yang berasal dari akar kata jablun (جطل ) yang berarti bodoh, sedangkan menurut al-Mu jam al-Wasit, istilah jahiliyah diartikan kedalam dua pengertian.

Pertama, berarti kondisi kebodohan dan kesesatan bangsa Arab sebelum kedatangan Islam ( كان عليه العرب قبل الإسلام من الجهالة و الضلالة). Kedua, berarti masa kekosongan di antara dua Rosul ( الفطرة بين رسولين زمن). Pengertian pertama memberi pemahaman bahwasanya semua kezaliman dan kebodohan pada masa itu disebut jahiliyah. Sedang pengertian kedua lebih membatasi, yaitu adanya suatu masa transisi (kekosongan) di mana masyarakat pada saat itu telah terlepas dari risalah kenabian Isa a.s dan belum menerima risalah kenabian Muhammad Saw. Menurut penelitian Tri Handayani dan Deddy Ilyas (2013) Berdasarkan sejarah Islam, tidak semua yang berhubungan dengan masa jahiliyah adalah sisi buruknya saja yang terlihat. Namun, ada sisi baiknya yang juga tetap diabadikan oleh agama Islam. Seperti sikap berani dan kewiraaan bansa Arab dalam membela suku, dan 
ibadah mengelilingi ka bah yang kemudian disempurnakan Islam menjadi ibadah haji. Islam menolak tradisi jahiliyah, terutama yang berhubungan dengan nilai-nilai theologis, etika dan budaya. Sebagaimana yang terjadi pada masa itu, pembunuhan terhadap bayi-bayi perempuan. Alqur'an pun mengabadikan peristiwa tersebut dalam surat an-Nahl ayat 58-59:

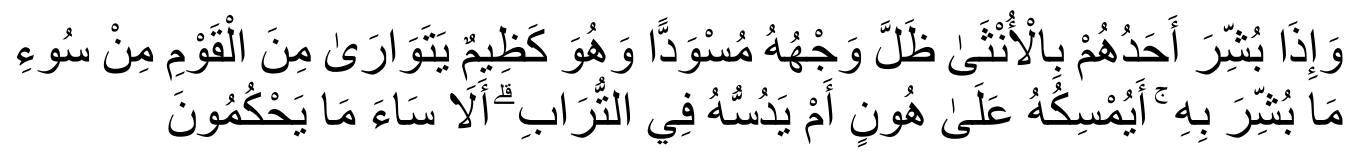

Artinya:

"Dan apabila seseorang dari mereka diberi kabar dengan (kelahiran) anak perempuan, hitamlah (merah padamlah) mukanya, dan dia sangat marah. Ia menyembunyikan dirinya dari orang banyak, disebabkean buruknya berita yang disampaikan kepadanya. Apakah dia akan memelibaranya dengan menanggung kehinaan ataukah akan menguburkannya ke dalam tanah (bidup-bidup)?. Ketahuilah, alangkah buruknya apa yang mereka tetapkan itu."

Mengenai ayat-ayat di atas, Ibnu Kathir berkata: Allah s.w.t mengatakan (kepada kita) tentang (kebiasaan) buruk orang-orang musyrik yang menyembah kepada selain Allah, dari patung dan berhala dan menyekutukan-Nya tanpa adanya pengetahuan. Apabila seseorang dari mereka diberi kabar dengan (kelahiran) anak perempuan, wajahnya menjadi pucat dan dia terpukul oleh rasa duka cita dan menghindari pergaulan dengan orang-orang. Dia akan merawatnya, namun, dengan terus menindas dan tidak memberikan kasih sayang dan mereka lebih memuliakan anak-anak laki-laki daripada anak perempuan, kalau tidak, dia akan menguburnya hidup-hidup, sebagaimana yang biasa mereka lakukan di zaman jahiliyah. Mereka beranggapan, kelahiran seorang anak perempuan hanya mendatangkan kehinaan dan malapetaka. Sebab, anak perempuan berbeda dengan anak laki-laki, anak perempuan fisiknya lemah, tidak dapat berperang dan hanya menanbah beban keluarga, ini dikarenakan tidak adanya peranan terhadap status perempuan pada masa jahiliyah (Nasif, 2001).

\section{b. Gender di Masa Kelahiran Islam}

Islam datang membawa pesan moral kemanusiaan yang tidak ada bandingnya dengan agama lain. Islam datang untuk membebaskan manusia dari belenggu kemanusiaan yang dipenuhi oleh kebodohan dan ketidakadilan. Islam datang membawa misi kesetaraan antara umat manusia. Karena, kemuliaan disisi Allah adalah nilai ketakwaan yang dimiliki. Dengan demikian, secara tegas dikatakan, tidak ada satu kebebasan individu dengan individu lainnya. Penghormatan kepada kaum perempuan terjadi pada saat kehidupan masyarakat Islam berada pda masa kenabian 
Muhammad s.a.w, yang mana dalam melaksanakan aktivitas, baik yang bersifat duniawi maupun yang bersifat ukhrowi, Rasullullah tidak pernah membedakan antara laki-laki maupun perempuan. Karena masing-masing individu memiliki hak serta kewajipan yang sama. Sebagaimana ditegaskan Allah dalam firmannya surat Ali-'Imran ayat 195:

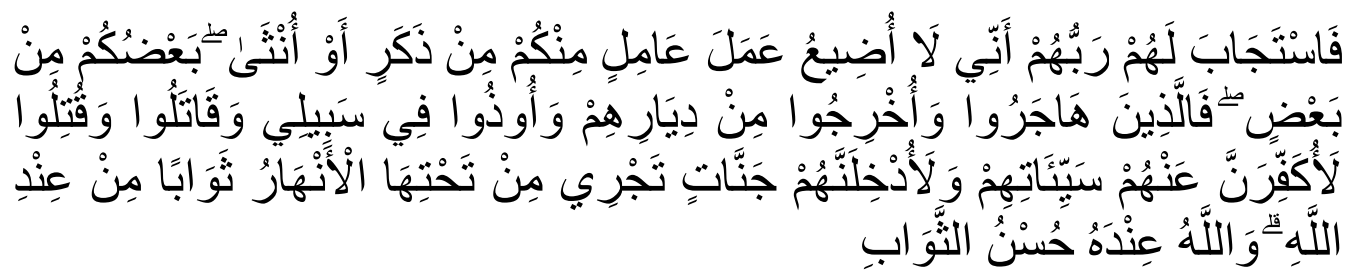

Artinya:

"Maka Tuban mereka memperkenankan permohonannya (dengan berfirman):"Sesunggubnya Aku tidak menyia-nyiakan amal orang-orang yang beramal di antara kamu, baik laki-laki atau perempuan, (karena) sebagian kamu adalah turunan dari sebagian yang lain. Maka orangorang yang berbijrah, yang diusir dari kampung halamannya, yang disakiti pada jalan-Ku, yang berperang dan yang dibunuh, pastilah akan Ku-hapuskan kesalaban-kesalaban mereka dan pastilah Aku masukean mereka ke dalam surga yang mengalir sungai-sungai di bawabnya, sebagai pahala di sisi Allah. Dan Allah pada sisi-Nya pabala yang baik".

Sejarah suram kehidupan kaum perempuan perlahan mulai berubah dalam masyarakat Islam periode Rasullullah, dimana pada saat tidak hanya dipandang sebagai seorang istri, pendamping, serta pelengkap kehidupan lelaki saja. Melainkan kaum perempuan juga telah dipandang sebagai anak manusia yang memiliki hak dan kewajipan yang setara dengan manusia lainnya yaitu lelaki. Tradisi jahiliyah sedikit demi sedikit mulai ditinggalkan, dan Rasullullah telah memulai tradisi baru dalam memandang kaum perempuan."Untuk mengatasi tradisi pembunuhan terhadap anak perempuan, Allah mentakdirkan Muhammad s.a.w tidak dikarunia anak lakilaki, dan dengan tanpa malu-malu Rasullullah menggendong anak perempuannya di depan khalayak (Hasyim, 2001).

Sejak awal Rasullullah mengajarkan Islam, prinsip persamaan derajat antara lelaki dan perempuan pun sudah ditanamkan, bahwa dalam hal ketaatan kepada Allah s.w.t, tidak ada beda antara kedua jenis manusia ini. Wacana ini benar-benar sesuatu yang baru, yang aneh terdengar di telinga kaum Arab yang kala itu sangat merendahkan kaum perempuannya. Seiring dengan semakin kuatnya akidah dan semakin kokohnya kekuatan umat, maka secara berangsur-angsur pula Allah s.w.t mengubahaturan-aturan lainnya yang berkaitan dengan kehidupan muslimah dan keluarga di tengah masyarakat. Diantaranya, aturan mengenai pembatasan poligami, 
pergaulan antara suami dan istri, perihal waris, pengakuan terhadap pentingnya peranan perempuan dalam keluarga, larangan melecehkan kaum perempuan, pengakuan terhadap hak-hak yang dimiliki perempuan, hingga terdapatnya penamaan salah satu surah Alqur'an dengan menggunakan nama atau istilah yang berhubungan dengan perempuan.

Pemulihan derajat kaum muslimah ini pun semakin didukung oleh teladan Rasullullah, baik dalam memperlakukan istri-istrinya dan kaum perempuan pada umumnya. Pentingnya kedudukan perempuan pada zaman Rasullullah dapat dilihat pada keterlibatan perempuan dalam bidang politik dan dalam peperangan. Ini menunjukkan bahwwa posisi kaum perempuan begitu diperhitungkan pada masa itu. Namun, semakin jauh dari kehidupan Rasullullah s.a.w, semakin pudar pula keterlibatan kaum perempuan dalam wacana publik. Jika pada masa Rasullullah s.a.w tingkat mobilitas dan keikutsertaan kaum perempuan dalam berbagai kegiatan sangat tinggi, mka kepergian Rasullullah s.a.w sebagai orang yang sangat membela kaum perempuan merupakan pukulan berat bagi kaum perempuan. Bila pada masa Rasullullah s.a.w perlakuan tersebut secara perlahan semakin pudar. Sepeninggal Rasullullah s.a.w kecenderungan pada superioritas laki-laki yang belum sepenuhnya terkikis oleh reformasi budaya Islam yang dilakukan Rasullullah s.a.w kembali menguat, seperti sikap yang diperlihatkan Umar ibn Khatab dalam suatu peristiwa dengan Nabi, menurut Umar: Memberikan hak terlalu banyak kepada kaum perampuan, sama artinya dengan membiarkan diri kita dikuasai oleh kaum peempuan. Ia menghendaki agar Islam lebih menekankan perubahan di dunia publik tetapi tetap mempertahankan moralitas pribadi berdasarkan tradisi Arab lama, karna itu, Umaar tetap menginginkan perempuan lebih banyak berperan di bidang domestic (Munhanif, 2002: 23).

Hal tersebut juga disebabkan karna sangat kurangnya akses perempuan di bidang penafsiran Alqur'an dan penetapan hukum Islam (fiqh), serta dominasi daripada sahabat laki-laki di bidang penafsiran ayat-ayat Alqur'an dan penetapan hukum Islam. Dari sini dapat difahami mengapa perspektif perempuan tidak pernah hadir dalam khazanah ke-Islaman, dan revolusi sosial yang dibawa Rasullullah s.a.w dalam hal kesetaraan antara laki-laki dan perempuan kian pudar. Seiring dengan berjalannya waktu,dalam sejarah umat Islam telah lahir berbagai karya tafsir yang ditulis oleh para ulama dalam rangka memberi penjelasan terhadap Alqur'an. Tidak 
jarang dalam kitab tersebut memuat suatu pendapat, fikiran atau wacana yang melihat perbedaan kelamin sebagai cara pandang terhadap ayat-ayat Alqur'an yang berakibat terjadinya diskriminasi gender dalam berbagai literatur tafsir yang ada, dan secara umum dapat dikatakan, pemahaman yang dimunculkan dari tafsir-tafsir klasik terhadap ayat-ayat gender selama ini bersifat memihak kepada laki-laki, dimana laki-laki diberikan peran dominan di bidang publik, sedang perempuan hanya terbatas pada wilayah domestik.

Sebagai contoh, apa yang dialami oleh sebagian perempuan di dunia saat ini sangatlah jauh berbeda dengan apa yang diterima kaum perempuan di zaman Rasullullah Saw. Sebagai gambaran, adalah kaum perempuan Indonesia. Perjalanan panjang yang dilalui kaum perempuan Indonesia telah melewati beberapa periode. Pada masa pra-Islam, sebagaimana yang dapat dibaca pada kitab-kitab kuno, kehidupan perempuan pada beberapa suku di Indonesia banyak di pengaruhi dari ajaran Hindu dan Budha. Gambaran fungsi dan peran sentral perempuan dalam kitab-kitab kuno tersebut pada umumnya sama. Meski pandangan tersebut bersumber dari kitab kuno, namun ajarannya masih berlku hingga zaman sesudahnya.

Pada masa kolonial, proses Islamisasi di Indonesia berlangsung secara aperlahan dan cenderung terhambat, dikarenakan banyaknya hambatan dan rintangan yang dialami para ulama, sehingga nilai-nilai dan ajaran Islam tidak dapat tersosialisasikan secara sempurna. Dan kehidupan sosial budaya lama yang masih membelenggu kehidupan perempuan (baca:istri), sebagai"konco wingking, surga nunut neroko katut" telah terlanjur merasuki pandangan hidup yang tidak mudah untuk diubah dengan cepat. Ajaran Islam yang belum menyentuh berbagai aspek kehidupan masyarakat dan terhambat oleh beberapa kendala, pada akhirnya tidak dapat mengubah nasib dan kehidupan kaum perempuan Indonesia, dan tentang fungsi dan peran perempuan masih belum beranjak dari sekitar peran reproduksi dan seksual. Budaya jawa yang banyak memberikan pengaruh dan kontribusi bagi kebudayaan Indonesia telah mewariskan sistem patriarkhi dalam kehidupan sosial di Indonesia. Dimana kehidupan seorang perempuan sepenuhnya berada dibawah kekuasaan laki-laki.

Dikotomi antara lelaki dan perempuan tersebut mencerminkan pengaruh sistem budaya masyarakat Indonesia yang umumnya patriarkat yang akhirnya 
mempengaruhi sikap politik dan kehidupan sosial negara Indonesia. Subordinasi dan diskriminasi terhadap perempuan pun telah memasuki dunia informasi dan hiburan, sebaimana diungkapkan Nadiroh Assariroh:"Eksploitasi terhadap perempuan juga semakin menggila, terutama melalui media, Semua berita menarik, sensasi dikonotasikan dengan perempuan. Citra perempuan diberitakan dengan jelek demi kegiatan kapitalistik. Semua iklan yang tertayangkan selalu di anggap menarik jika memunculkan sosok peempuan. Pelacur punya konotasi perempuan, menyeleweng juga perempuan. Perempuan semakin dipojokkan dan semakin di bendakan (Bainar, 1998).

Secara umum perempuan selalu dimunculkan sebagai sosok yang bermasalah ketika dikaitkan dengan organ-organ tubuhnya. Sudah berpuluh abad lamanya pandangan ini mewarnai hampir seluruh budaya manusia, dan kemudian mendapatkan legitimasi dari agama-agama besar seperti, Yahudi dan Kristen. Kedua-dua agama diatas mempunyai pandangan yang hampiar sama karna persamaan latar budaya. Tuhan yang dinisbahkan dalam citra ke-lelakian (maskulin) dalam bahasa kedua-dua kitab suci agama tersebut diatas, bagaimana pun sangat mempengaruhi pola relasi gender umatnya. Kepercayaan bahwa Adam adalah manusia pertama, dan sementara Hawa (Eva) diciptakan dari tulang rusuknya telah mewarnai pemikiran sebagian kalangan, meskipun dalam kasus ini tidak satupun ayat Alqur'an yang mengungkapkan penciptaan Hawa. Al-Qu’an hanya menunjukkan bahwa Adam dan pasangannya diciptakan dari dzat yang sama. Adapun yang menjadi sumber rujukan Islam terhadap masalah di atas adalah hadits Nabi s.a.w, diriwayatkan Imam al-Bukhari (J.7, 1981) yang menyatakan bahwa perempuan diciptakan dari tulang rusuk yang bengkok.

"Dari Abu Hurairah ra bahwasanya Rasullullah s.a.w bersabda: perempuan itu seperti tulang rusuk, jika engkau meluruskannya (dengan paksa), tentulah ia patah. Dan jika engkau beri ia kesenangan, tentulah ia menikmati kesenangan itu, dan ia masih saja bengkok". Adapun mengenai tulang rusuk yang dipercaya sebagai asal-usul perempuan, banyak tanggapan dari para ulama, diantaranya adalah Prof. Dr. M. Quraish Shihab, menurut beliau; tulang rusuk yang bengkok harus dipahami dalam pengertian kiasan (majar), dalam arti bahwa hadis tersebut memperingatkan para laki-laki agar menghadapi perempuan dengan bijaksana. Karena ada sifat, karakter, dan kecenderungan mereka yang tidak sama dengan laki-laki, hal ini bila 
tidak disadari dapat mengantar kaum lelaki untuk bersikap tidak wajar. Mereka tidak akan mampu mengubah karakter dan sifat bawaan perempuan. Kalupun mereka berusaha, akibatnya akan fatal, sebagaimana fatalnya meluruskan tulang rusuk yang bengkok (Shihab, 2001).

Sepeninggal Nabi Saw, kecenderungan pada superioriti lelaki yang belum sepenuhnya terkikis oleh reformasi budaya Islam kembali menguat. Sehingga perlu upaya reinterpretasi yang gigih untuk mengembalikan pada yang sebenarnya.

\section{Kewenangan dan Kedudukan Perempuan pada Zaman sebelum Islam}

Pada zaman pra-Islam terdapat beberapa kebudayaan zaman jahiliyyah, salah satunya yaitu kebiasaan membunuh anak perempuan. M. Quraish Shihab menyebutkan tiga alasan terjadinya pembunuhan pada zaman jahiliyyah. Pertama, orang tua pada masa masyarakat jahiliyah takut jatuh miskin bila menanggung biaya hidup anak perempuan yang dalam konteks zaman itu, tidak bisa mandiri dan produktif. Kedua, masa depan anak-anak dikhawatirkan mengalami kemiskinan (jatuh miskin). Anak perempuan dikubur karena orang tuanya khawatir anak-anak perempuan diperkosa atau berzina. Ketiga, sesuai dengan seringnya konflik antar kabilah atau peperangan antarsuku, orang tua khawatir anaknya akan ditawan musuh dalam peperangan itu (Monib dan Bahrawi, 2011).

Alasan mereka bahwa anak perempuan adalah biang dari petaka karena dari segi fisik perempuan lebih lemah daripada laki-laki. Ketika lemah, secara otomatis akan menjadi batu sandungan bagi sang ayah atau ketua kelompok dan tidak bisa diajak berperang. Dan akan mengurangi pengaruh kabilahnya dalam percaturan dunia, penghambat pembangunan, kurang bisa mandiri dan menggantungkan pada laki-laki dan itu semua adalah aib bagi mereka maka harus ditutupi kalau perlu dibuang. Dengan fenomena tersebut, menurut Fatah Syukur (2011) hak-hak perempuan tidak terpenuhi bahkan tidak akan terpenuhi. Penghormatan dan pengagungan kaum perempuan berubah menjadi pelecehan seksual dan psikologi. Inilah salah satu yang ditentang Islam sesuai dengan firman Allah dalam QS. Al-Hujurat ayat 13:

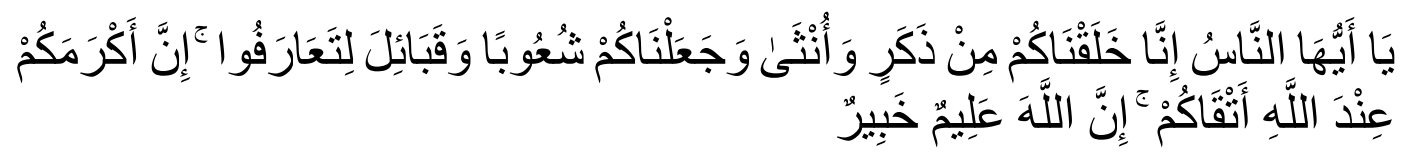

Artinya:

"Hai manusia, sesunggubnya Kami menciptakan kamu dari seorang laki-laki dan seorang perempuan dan menjadikan kamu berbangsa-bangsa dan bersuku-suku supaya kamu saling kenalmengenal. Sesunggubnya orang yang paling mulia diantara kamu disisi Allah ialah orang yang paling takwa diantara kamu. Sesungguhnya Allah Maha Mengetahui lagi Maha Mengenal”. 
Menurut Quraish Shihab, catatan terpenting yang ingin ia sampaikan ialah bahwa tradisi mengubur anak perempuan hidup-hidup bukan adat yang memperoleh restu dari semua kabilah Arab Jahiliyyah karena kenyataannya, sebagian kabilah justru memberikan tebusan berupa unta bagi orang tua yang bermaksud mengubur anak perempuannya. Sha'sha'ah bin Najiah, kakek al- Farazdaq, penyair kenamaan zaman Jahiliyyah, yang memberikan dua ekor unta hamil sepuluh bulan kepada orang tua yang akan membunuh anak perempuannya. Mohammad Monib dan Islah Bahrawi (2011) mengungkapkan bahwa konon, Sha'sha'ah bin Najiah sempat menyelamatkan sekitar 300-400 orang anak perempuan yang akan dikubur hidup-hidup dengan tebusan unta.

Walaupun masih ada kabilah yang kontra terhadap penguburan hidup-hidup bayi perempuan tetapi kebiasaan tersebut sudah menjadi budaya yang mengakar dan sudah umum dipraktekkan oleh masyarakat Arab Jahiliyyah pada masa itu. Adat-istiadat Jahiliyah yang berlaku pada masa itu, selain mengubur hidup-hidup setiap bayi perempuan yang dilahirkan, yaitu mengawini perempuan sebanyak yang disukai dan menceraikan mereka sesuka hati, sampai pernah ada kepala suku yang mempunyai tujuh puluh hingga sembilan puluh istri. Sebagaimana dimaklumi, masyarakat Arab zaman Jahiliyyah mempraktekkan bermacam-macam pola perkawinan. Ada yang disebut nikah ad-dayzan, dimana anak sulung laki-laki dibolehkan menikahi janda (istri) mendiang ayahnya. Caranya sederhana, cukup dengan melemparkan sehelai kain kepada perempuan itu, maka saat itu juga dia sudah mewarisi ibu tirinya itu sebagai istri. Kadangkala dua orang bapak saling menyerahkan putrinya masing-masing kepada satu sama lain untuk dinikahinya. Praktek ini mereka namakan nikah as-syighr. Ada juga yang saling bertukar istri hanya dengan kesepakatan kedua suami tanpa perlu membayar mahar, yaitu nikah al-badal. Selain itu ada pula yang dinamakan zawaj al istibdha', dimana seorang suami boleh dengan paksa menyuruh istrinya untuk tidur dengan lelaki lain sampai hamil dan setelah hamil sang istri dipaksa untuk kembali kepada suaminya semula, semata-mata karena mereka ingin mendapatkan bibit unggul dari orang lain yang dipandang mempunyai keistimewaan tertentu. Bentuk-bentuk pernikahan semacam ini jelas sangat merugikan dan menindas perempuan (Arif, 2008).

Namun demikian, Nasy'at Al-Masyri (1989) menyatakan Ada juga jenis pernikahan yang disebut dengan nikah al-mukhadanah, yaitu pernikahan seorang perempuan yang mempunyai banyak suami (poliandri). Hal seperti ini banyak terjadi antar saudara di kalangan bangsa Arab. 
Dari uraian tersebut dapat dilihat bahwa kaum perempuan pada masa pra-Islam atau yang lebih dikenal dengan zaman Jahiliyyah terlihat jelas praktik-praktik kehidupan yang ada belum menunjukkan kesetaraan gender. Hal ini disebabkan kaum laki-laki Arab Jahiliyyah belum memahami hak-hak asasi manusia khususnya hak-hak perempuan. Perempuan dianggap hina dengan alasan berbagai kelemahankelemahannya. Padahal kelemahan perempuan itu bukan karena memang tidak mampu tetapi karena keterbatasan para perempuan yang tidak diberi ruang gerak untuk mengaktualisasikan diri. Jadi, kewenangan dan kedudukan perempuan di zaman Jahiliyyah itu sangatlah lemah serta kaum perempuan dipandang tidak memiliki kemanusiaan yang utuh dan oleh karenanya perempuan tidak mempunyai kebebasan/tidak berhak bersuara, tidak berhak berkarya, dan tidak berhak memiliki harta. Bahkan, eksistensinya sebagai makhluk manusia pun dipertanyakan. Hal ini berbeda dengan hasil penelitian yang dilakukan oleh Jamal Ma'mur (2016), ia mengungkapkan bahwa perempuan masa Nabi mengikuti shalat jama'ah, shalat jum'ah, shalat idul fithri dan idul adha. Mereka juga, menghadiri majlis ilmu dan berada di medan perang. Perempuan juga boleh bekerja di luar rumah dengan syarat profesinya dibolehkan agama dan tidak diharamkan, konsisten menjaga etika Islam, dan tidak meninggalkan kewajiban utamanya kepada suami dan anak-anak; dalam konteks publik, perempuan boleh menjadi pemimpin; dan lain-lain.

\section{Kewenangan dan Kedudukan Perempuan dalam Historis Islam}

Pada masa Rasulullah, kaum perempuan muslimah tampak dalam sosok perempuan yang dinamis, sopan, dan terpelihara akhlaknya. Bahkan dalam al Qu'an, figur ideal seorang muslimah disimbolkan sebagai pribadi yang memiliki kemandirian politik, al-istiqlāl al-siyassah (QS. al-Mumtahanah [60]), seperti figur Ratu Bilqis yang mempunyai kerajaan 'arsyun 'ąhim (superpower), dan figur-figur yang lain. Gambaran yang demikian ideal ini tidak ditemukan dalam kitab-kitab suci agama lain. Tidaklah mengherankan jika pada masa Nabi ditemukan sejumlah perempuan memiliki kemampuan prestasi cemerlang sebagaimana yang diraih kaum laki-laki. Dalam jaminan al-Qur'an, perempuan dengan leluasa memasuki semua sector kehidupan masyarakat, termasuk politik dan ekonomi.

Ada sebuah hadits yang cukup popular dan seringkali dijadikan dalil yang menganggap bahwa tidak akan beruntung satu kaum bila diserahkan kepada perempuan. Padahal anggapan tersebut adalah salah kaprah karena menggeneralisasi 
kasus tertentu yang sebenarnya berlaku hanya untuk kondisi yang dimaksud dalam hadits tersebut. Berikut terjemahan hadits yang saya kutip di buku Wawasan al-Qur'an karya Quraish Shihab.”Ketika Rasulullah SAW. Mengetahui bahwa masyarakat Persia mengangkat putri Kisra sebagai penguasa mereka, beliau bersabda,"Tidak akan beruntung satu kaum yang menyerahkan urusan mereka kepada perempuan.” (Diriwayatkan oleh Bukhari, al-Nasa'i, dan Ahmad melalui Abu Bakrah). Hadits tersebut di atas ditujukan kepada masyarakat Persia ketika itu, bukan tehadap semua masyarakat dan dalam semua urusan. Quraisy Shihab menyimpulkan bahwa tidak ditemukan satu ketentuan agama pun yang dapat dipahami sebagai larangan keterlibatan perempuan dalam bidang politik, atau ketentuan agama yang membatasu bidang tersebut hanya untuk kaum lelaki. Di sisi lain, cukup banyak ayat dan hadits yang dapat dijadikan dasar pemahaman untuk menetapkan adanya hak-hak tesebut (Shihab, 1996).

Dalam sejarah Islam, Asghar Ali Engineer (1999) menjelaskan peran perempuan dalam sektor publik dapat dibuktikan dalam kisah istri-istri Nabi. Kita menemukan di dalam Shabih Bukhori, salah satu kumpulan hadits yang otentik, menyebutkan bahwa perempuan muslim secara aktif membantu mereka yang luka dalam perang Uhud, termasuk di dalam kaum perempuan ini adalah para istri Nabi sendiri. Satu orang menggambarkan bahwa ia melihat Aisyah dan istri Nabi yang lain membawa air untuk kaum laki-laki di medan perang. Aisyah meriwayatkan hadits bahwa dia (Aisyah) menemani Nabi dalam sebuah perang, dan ini terjadi setelah turunnya ayat tentang cadar.

Azyumardi Azra (2000) menyebutkan bahwa, pada zaman Nabi Muhammad SAW., belum ada larangan perempuan menjadi pemimpin. Bahkan Aisyah (istri Nabi) saja pernah menjadi pemimpin perang. Maka sangat wajar jika dalam lintas sejarah umat Islam terdapat tokoh perempuan yang berperan sebagai pemimpin, tokoh ulama, dan perawi hadits. Pada masa Nabi, tercatat ada 1.232 perempuan yang menerima dan meriwayatkan hadits. Bahkan Ummul Mukminin Aisyah ra. tercatat sebagai salah seorang dari tujuh bendaharawan hadits. Beliau meriwayatkan 2.210 hadits. Khadijah binti Khuwailid, istri Nabi yang pertama, dikenal sebagai perempuan yang sukses dalam dunia bisnis. Al-Syifa' tercatat sebagai perempuan yang ditunjuk Khalifah Umar sebagai manajer pasar di Madinah, sebuah pasar besar di ibu kota pada waktu itu. Zainab, istri Nabi, menyamak kulit dan hasilnya disedekahkan. Zainab istri Ibn Mas'ud dan Ama' 
binti Abu Bakar keluar rumah mencari nafkah untuk keluarga. Di Medan perang, banyak nama sahabat perempuan yag tercatat sebagai pejuang, baik di garis belakang seperti mengobati prajurit yang luka dan menyediakan logistik maupun di garis depan memegang senjata berhadapan dengan lawan. Nusaibah binti Ka'ab tercatat sebagai perempuan yang memanggul senjata melindungi Rasululah ketika perang Uhud. AlRabi' binti al-Mu'awwidz, Ummu Sinan, Ummu Sulaim, Ummu Athiyah, dan sekelompok perempuan lain juga beberapa kali ikut turun ke medan laga. Catatan mengenai keberanian mereka dapat kita jumpai dalam banyak hadits shahih dan bukubuku sejarah yang terkenal (Siraj, 2006).

Akan tetapi, sejarah mencatat bahwa kedudukan perempuan pasca Nabi bukan semakin membaik, melainkan semakin jauh dari kondisi ideal. Sepeninggal Nabi, perempuan mukmin kembali mengalami mengalami eksklusi dari ruang publik. Hal itu mengindikasikan bahwa umat Islam pasca Nabi tak sepenuhnya berhasil menepis biasbias patriarkhi yang secara kuat mengakar dalam masyarakat Arab pra-Islam, dan di berbagai masyarakat lainnya dimana Islam tersiar. Beberapa kaum feminis radikal menuduh bahwa ajaran Islam yang tertuang dalam ayat-ayat gender menyebabkan subordinasi perempuan sehingga menimbulkan ketidakadilan gender yang merugikan pihak perempuan.

Syekh Abdul Halim Muhammad Abu Syuqqoh dalam karya monumentalnya, Tahrir al-Mar'ah fi 'Ashr al-Risalah, misalnya, membuktikan bahwa tidak seperti yang sering dituduhkan, agama Islam ternyata sangat emansipatoris. Setelah melakukan studi intensif atas literature Islam Klasik, beliau mendapati bahwa kedatangan Islam telah menyebabkan terjadinya revolusi gender pada abad ke-7 Masehi. Agama samawi terakhir ini justru datang memerdekakan perempuan dari dominasi kultur Jahiliyyah yang dikenal sangat zalim dan biadab itu. Abu Syuqqah juga menemukan bahwa pasca datangnya Islam kaum perempuan mulai diakui hak-haknya sebagai layaknya manusia dan warga Negara (bukan sebagai komoditi), terjun dan berperan aktif dalam berbagai sektor, termasuk politik dan militer. Kesimpulan senada juga dicapai oleh para peneliti Barat. Setelah ditelusuri dan diteliti lebih jauh, maka didapati bahwa ternyata kaum perempuan pada zaman Nabi Muhammad SAW lebih maju dan diakui hak-hak asasinya ketimbang pada masa pra-Islam. Oleh karena itu tidaklah berlebihan jika dikatakan bahwa gerakan emansipasi perempuan dalam sejarah peradaban manusia sebenarnya dipelopori oleh risalah yang dibawa Nabi Muhammad SAW. Kedatangan 
Islam telah mengeliminasi budaya-budaya Jahiliyyah dan dihapuskan untuk selamalamanya (Arif, 2006).

\section{Hasil Analisis Kajian Kewenangan dan Kedudukan Perempuan}

Secara historis, proses penciptaan manusia telah disebutkan dalam Alqur'an. Penafsiran terhadap ayat tersebut memberi pengaruh terhadap pemahaman gender laki-laki dan perempuan. Ketika ditafsirkan bahwa Adam dan Hawa diciptakan dari jenis yang sama yaitu diri manusia maka dapat dipahami bahwa Adam dan Hawa memiliki kedudukan yang setara. Tetapi ketika ditafsirkan bahwa Hawa diciptakan dari tulang rusuk Adam, ada anggapan bahwa penafsiran tersebutlah yang mengakibatkan terjadinya subordinasi perempuan sehingga terjadi ketidakadilan gender. Tetapi ada penafsiran lain yang dibuktikan secara ilmiah, bahwa ada potensi Hawa diciptakan dari tulang rusuk Adam dapat dijelaskan melalui proses biologi yang dikenal dengan cloning. Cloning yang dimaksud ditujukan kepada salah satu hadis Nabi yang menyebutkan bahwa perempuan adalah mitra lakilaki. Mitra yang dimaksud dalam hadis tersebut dibahasakan dalam bahasa biologi yakni cloning. Sebagai mitra, tentu memiliki tingkat yang setara dan saling mnghargai satu sama lain. Pada zaman sebelum Islam, perempuan pernah mengalami masamasa suram. Terbentuknya budaya masyarakat pada zaman jahiliyyah memposisikan perempuan sebagai sosok yang tidak berharga bahkan sampai terjadi bayi-bayi yang baru lahir dengan jenis kelamin perempuan dikubur hidup-hidup oleh orang tuanya sendiri karena dianggap tidak berguna. Perempuan tidak mempunyai ruang kebebasan dan tidak memiliki kesempatan selayaknya peran yang bisa dilakukan laki-laki. Bahkan perempuan sebagai istri bisa diwariskan dan dipertukarkan sesuka hati laki-laki tanpa meminta persetujuan istri, seolah perempuan bukan manusia.

Hingga akhirnya Nabi Muhammad SAW datang membawa ajaran Islam merubah budaya masyarakat jahiliyyah dengan ajaran yang mengangkat dan memuliakan harkat dan martabat perempuan. Dari posisi perempuan yang tidak dihargai sama sekali, yang dulunya perempuan diwariskan kepada laki-laki kemudian Islam mengangkat posisi perempuan sehingga bisa mewarisi harta setengah dari bagian laki-laki. Perempuan lebih dihargai dengan adanya hukum perkawinan Islam yang memerintahkan untuk mempergauli istri dengan baik sehingga hak-hak sebagai perempuan telah diwujudkan, tidak lagi menjadi bahan hinaan tetapi perempuan diakui keberadaannya sebagai manusia. Bahkan pada masa nabi, permpuan memiliki andil 
dalam berbagai sektor kehidupan sebagaimana kisah istri-istri nabi seperti khadijah yang menjadi pebisnis handal, aisyah pernah memimpin perang, dan lain sebagainya. Pada masa dinasti Islam pun perempuan juga memiliki pengaruh penting dalam politik dinasti walaupun pada akhirnya juga terjadi kemunduran. Sedangkan dalam periode modern perempuan juga bisa berperan dalam berbagai sektor kehidupan termasuk menjadi kepala Negara seperti yang pernah terjadi di Indonesia yakni presiden perempuan pertama kali, Megawati Soekarnoputri.

Sungguh hal ini merupakan kemajuan yang luar biasa dalam upaya penyetaraan gender. Sebagaimana yang disebutkan dalam firman Allah bahwa sesungguhnya yang paling mulia di sisi Allah adalah yang paling bertakwa, bukan karena jenis kelaminnya laki-laki bukan juga karena jenis kelaminnya perempuan. Sehingga dapat dirasakan hingga saat ini sudah banyak perempuan yang berkarir dengan berbagai jenis pekerjaan, misal; dokter, dosen, guru, supir bus, kondektur, pegawai, buruh bangunan, hakim, presiden, pilot, dan profesi lainnya.

\section{SIMPULAN}

Gender adalah peran, sifat, maupun tingakah laku yang dilekatkan padalaki-laki atau perempuan yang merupakan hasil konstruksi sosial budaya. Dalam proses penciptaan manusia yang dikisahkan dalam al-Qur'an menuai kontroversi dalam penafsiran. Terutama penafsiran al-Thabari yang menyatakan bahwa Hawa diciptakan dari tulang rusuk Adam dianggap menyebabkan subordinasi perempuan sehingga mengakibatkan ketidakadilan gender. Tetapi pendapat lain secara ilmiah bisa membuktikan bahwa bisa jadi terjadi proses cloning manusia yang dilakukan oleh Tuhan. Tetapi cloning yang dimaksud adalah mitra sehingga perempuan harus diperlakukan dengan baik.

Hasil kajian ini menunjukan bahwa pada zaman pra Islam dalam budaya masyarakat Arab Jahiliyyah, perempuan mendapat perlakuan yang tidak baik, dianggap sebagai sosok yang tidak berdaya, tidak dihargai, tidak setara dengan laki-laki, ditindas dan dianggap tidak berguna bahkan aib keluarga. Tidak menunjukkan adanya kesetaraan gender. Setelah Islam datang, kedudukan perempuan diangkat, dihargai, dilindungi, dan disetarakan dengan kaum laki-laki. Pada periode klasik, zaman nabi, utamanya perempuan termasuk istriistri nabi memiliki peran penting dalam kehidupan pada masa itu, dalam bidang periwayatan hadis, perang, bisnis, dll bahkan perempuan mampu menjadi pemimpin dalam perang seperti yang pernah dilakukan oleh istri Nabi Aisyah. Pada periode pertengahan, zaman 
dinasti-dinasti Islam, perempuan juga memiliki peran penting dalam kehidupan politik bahkan mampu bersaing dalam perlombaan syair yahng kala itu menjadi trend dan bergengsi walaupun pada akhirnya mengalami kemunduran. 


\section{DAFTAR REFERENSI}

Al-Hamdani, Sa'id Talib. (1989). Risalah Nikah Hukum Perkawinan Islam. Jakarta: Pustaka Amani.

Al-Masyri, Nasy'at. (1989). Nabi Suami Teladan. Terj. Salim Basyarahil. Jakarta: Gema Insani Press.

Arif, Syamsuddin. (2006). "Wanita dan Keluarga Citra Sebuah Peradaban”. Al-Insan: Jurnal Kajian Islam. No. 3. Vol. 2. . (2008). Orientalis \& Diabolisme Pemikiran. Jakarta: Gema Insani.

Azra, Azyumardi. (2000). Islam Substantif: Agar Umat Tidak Jadi Buih. Jakarta: Mizan.

Badudu, S. dan Sultan Mohammad Zain. 2001. Kamus Umum Bahas Indonesia. Jakarta: Pustaka Sinar Harapan.

Bainar. (1998). Wacana Perempuan dalam ke-Indonesiaan dan kemodernan. Jakarta: PT. Pustaka Cidesindo.

Echols, John M. dan Hasan Shadiliy. (1983). Kamus Inggeris Indonesia. Jakarta: Gramedia.

Engineer, Asghar Ali. (1999). Pembebasan Perempuan. Yogyakarta: LkiS.

Fadlan. (2011). "Islâm, Feminisme, dan Konsep Kesetaraan Gender Dalam Al-Qur'ân”. Jurnal KARSA. Vol. 19. No. 2.

Handayani, Tri dan Deddy Ilyas. (2013). "Isu Gender: Potret Relasi Masa Lampau”. JIA. Th. XIV/Nomor 1.

Hasyim, Syafiq. (2001). Hal-Hal Yang Tak. Terpikirkan Tentang Isu-isu Keperempuanan Dalam Islam. Bandung: Mizan.

Hasyim, Zulfahani. (2012). "Perempuan dan Feminisme dalam Perspektif Islam". Jurnal Muwẫâah. Volume. 4. Nomor. 1.

Karim, Abdul. (2014). "Kerangka Studi Feminisme (Model Penelitian Kualitatif tentang Perempuan dalam Koridor Sosial Keagamaan). Jurnal Fikrah. Vol. 2. No. 1.

Ma'mur, Jamal. (2016). "Moderatisme Fikih Perempuan Yusuf Al-Qardhawi". Jurnal Muwazah. Vol. 8. No.1.

Macdonald, Mandy dkk. (1999). Gender dan Perubahan Orgnisasi. terj. Omi Intan Naomi. Jakarta: Insist.

Monib, Mohammad dan Islah Bahrawi. (2011). Islam dan Hak Asasi Manusia dalam Pandangan Nurcholish Madjid. Jakarta: Gramedia Pustaka Utama. 
Munhanif, Ali. (2002). Perempuan dalam Literatur Islam Klasik. Jakarta: Gramedia Pustaka Utama.

Munir, Lily Zakiyah. (1999). Memposisiken Kodrat. Bandung: Mizan.

Muslikhati, Siti. (2004). Feminisme dan Pemberdayaan Perempuan dalam Timbangan Islam. Jakarta: Gema Insani Press.

Mutawakkil, M. Hajir. (2014). “Keadilan Islam dalam Persoalan Gender”. Jurnal Kalimah. Vol. 12. No. 1.

Nasif, Fatimah Umar. (2001). Menggugat Sejarah Perempuan. Jakarta: Cendikia.

Neuvelt, Victoria. (1984). Webster's New World Dictionary. New York: Webster's New World Clevenland.

Ramli, Mohd Anuar. (2012). "Gender Analysis in Islamic Jurisprudence”. Journal of Fiqh. No. 9.

Rohmaniyah, Inayah. (2009). "Gender dan Kontruksi Perempuan dalam Agama”. Jurnal Studi Ilmu-iImu AI-Qur'an dan Hadis. Vol. 10. No. 2.

Shihab, M. Quraish. (2001). Wawasan al-Qur'an: Tafsir Tematik atas Pelbagai Persoalan Umat. Bandung: Mizan.

Siroj, Said Aqil. (2006). Tasawuf Sebagai Kritik Sosial. Bandung: Mizan.

Starda, Ronni. (2010). Sabda Nabi tentang Perempuan Serumpun Bunga dari Rasulullah. Jakarta: Elex Media Komputindo.

Subhan, Zaitunah. (2004). Perempuan dan Politik dalam Islam. Yogyakarta: Pustaka.

Suryorini, Ariana. (2012). "Menelaah Feminisme dalam Islam". Jurnal Sawwa. Volume. 7. Nomor. 2.

Syukur, Fatah. (2011). Sejarah Peradaban Islam. Semarang: Pustaka Rizki Putra.

Tierney, Helen. (1993). Women's studies Encyclopedia. New York: Green Wood Press.

Umar, Nasaruddin. (2001). Argumen Kesetaraan Jender Perspektif al-Qur'an, Jakarta: Paramadina 